Regrettably many dentists cruising

gently towards retirement will often

assume that business planning is

something they can ignore, because it

seems less relevant as they will soon be

retired.

\title{
Have you an exit route?
}

I was recently reminded of the difficulty some dentists have on retirement when a colleague informed me that he was intending to retire in a few weeks but had failed to find a buyer for his dental practice. This is a familiar story, and seems to have worsened in the last few years for some unlucky dentists who just cannot seem to find anyone to purchase their practice. As a result they may end up selling as a residential sale simply to realise some of the equity of the property. In effect they have not been able to sell the dental practice as a business at all.

Naturally the repercussions of this can be devastating if the practitioner has been relying on the sale of both practice and goodwill as a substantial part of a pension plan. Not everyone can find a corporate body eager to purchase their practice and this situation may worsen with the proposed changes in the law regarding corporate dentistry. However, the problem is that too few dentists consider their 'exit route' when they carry out their business planning, if they understand the concept of 'exit route' at all.

In business terms an exit route is the term for your 'exit' from the business, usually by selling it. In fact most people who own a business have the sale of the business as their ultimate objective, hopefully for considerable profit. In contrast most health professionals running a business concern themselves more with the provision of making enough profit to provide them with an appropriate salary. This means that the professional, for example a general dental practitioner, considers his or her practice to be a method of enabling them to combine practising their chosen profession of dentistry with the service of providing oral care for the public. The business person considers the business from the viewpoint of increasing its value to a potential purchaser, which obviously means increasing its profit-earning potential but also increasing its value as an attractive asset. The dentist is often more focused on the process of the practice (the dentistry) and less on the outcome of the business (the sale of the practice).

Of course, focusing on the exit route does not mean that the running of the business is ignored, or that the service provided is any less important. Part of the value of any business is the success with which the business provides a quality service or products for its market. The exit route should simply be a major consideration in the business planning and strategic thinking of the owner of the business, influencing decisions that will affect what happens in all stages of running the business. For example a decision in a particular area to create a specialist practice, set up an NHS practice or convert an existing practice from NHS to private should consider how attractive that practice might be in the future to a potential buyer.

Considering your exit route relies on a basic understanding of strategic forecasting (what you think is going to happen in the future) and marketing. The importance of the former is obvious, and the further away your potential exit from the practice is - the more you need to be able to forecast future changes and adapt as the world of dentistry changes.

The importance of marketing is perhaps less obvious, but usually more important. Part of your marketing strategy should be to create the type of practice that will be attractive to potential purchasers, and you can choose (to an extent) who that purchaser might be. Your choices of purchaser may include newly qualified practitioners, corporate bodies and established dentists looking to expand. In order to be attractive you will need to research into what each one is looking for, and then develop your own practice accordingly.

Thus having an exit route is an important part of overall business planning, and you can never start too early. Regrettably many dentists cruising gently towards retirement will often assume that business planning is something they can ignore, because it seems less relevant as they will soon be retired. The reverse is true. Unless they have already planned their exit route then business planning is vital if they are to be successful in achieving the successful sale of their dental practice.

\section{Mike Grace \\ m.grace.bdj@bda-dentistry.org.uk}

